\title{
Integrity of the preimplantation pig blastocyst during expansion and loss of polar trophectoderm (Rauber cells) and the morphology of the embryoblast as an indicator for developmental stage*
}

\author{
P. M. G. Barends, H. W. J. Stroband, N. Taverne, G. te Kronnie, \\ M. P. J. M. Leën and P. C. J. Blommers \\ Agricultural University, Department of Experimental Animal Morphology and Cell Biology, \\ ZODIAC, Marijkeweg 40,6709 PG Wageningen, The Netherlands
}

\begin{abstract}
Summary. The embryonic ectoderm of the pig differentiated and became part of the outer barrier of the blastocyst (earlier formed by the trophectoderm alone) before shedding of the overlying polar trophectoderm around Day 10, thus securing the integrity of the rapidly expanding blastocyst. Ferritin, added to the medium of the blastocyst, was taken up rapidly by trophectoderm cells, but did not reach the blastocoele, and consequently no tracer was found within hypoblast cells. Embryonic ectoderm cells did not absorb the macromolecule, before or after loss of the polar trophectoderm. When ferritin was injected into the blastocoele, trophectoderm, hypoblast and embryoblast cells all absorbed the tracer. At Day 11, blastocyst diameter and embryoblast cell number varied widely and were hardly correlated. We suggest that embryoblast development may be a more reliable indicator for the developmental stage of a blastocyst than its diameter, which may merely be an indication of the viability of the trophoblast.
\end{abstract}

Keywords: pig; blastocyst; ultrastructure; developmental variation

\section{Introduction}

The early mammalian blastocyst consists of an inner cell mass (ICM) and outer trophectoderm cells. The latter form a layer of polarized cells (Ducibella, 1977; Reeve, 1981), which is selectively permeable and responsible for the creation of a microenvironment within the blastocyst (Biggers et al., 1988). It has been shown that transport of ions such as $\mathrm{Ca}^{2+}$ and of fluid contributes to the formation of the blastocoele (Schlafke \& Enders, 1967; Kaufman, 1983). The presence of junctional complexes between the trophectoderm cells appears to be the morphological condition for these nett transport processes (McLaren \& Smith, 1977).

The inner cells differentiate much later. In most species they are surrounded by trophectoderm cells until implantation which usually starts almost immediately after hatching of the blastocyst from the zona pellucida. In ungulates, however, the preimplantation period is prolonged. In the pig, hatching takes place at Day 6 (Perry \& Rowlands, 1962; Hunter, 1977), while attachment of trophectoderm to the uterine epithelium does not take place before Day 13 (Dantzer, 1985). In cow (Betteridge \& Fléchon, 1988), horse (Enders et al., 1988) and pig (Geisert et al., 1982; Stroband et al., 1984) the trophectoderm cells covering the ICM ('polar trophectoderm' or 'Rauber cells') disappear some days after hatching: in the pig usually around Day 10 when the rapidly expanding blastocysts have reached a mean diameter of $3 \mathrm{~mm}$. As a consequence, ICM cells form a part of the

*Reprint requests to Dr H. W. J. Stroband. 
outer cell layer from that moment onwards. The pig blastocysts continue to expand to a diameter of about $10 \mathrm{~mm}$ at Day 11-12, followed by rapid tubulation and filamentation shortly before attachment takes place.

The question arises of whether and how the selectively permeable seal, formed by the trophectoderm, is maintained after the loss of Rauber's cells. As a part of this largely ultrastructural study, blastocysts were also incubated in a ferritin solution, or ferritin was injected into the blastocoele, to study the possible uptake and transport of macromolecules.

It has been suggested that within-litter variation in embryo development might be a cause of embryonic mortality (Pope \& First, 1985; Wilmut et al., 1985; Pope et al., 1986). Reports on pig blastocyst development use mainly its diameter as an indicator for developmental stage. However, Wright et al. (1983) found no correlation between blastocyst volume and blastocyst protein between Days 6 and 9, throwing doubt on the significance of a measure such as blastocyst diameter. In this report, the cell number of the embryoblasts and the diameter of the blastocysts were determined in an attempt to verify the value of blastocyst diameter as an indicator for variation in embryo development.

\section{Materials and Methods}

For the ultrastructural study, 36 Yorkshire-Dutch Landrace interbreed gilts (Y/DL) were used. All these gilts were inseminated artificially on Day 0 of their third oestrus (i.e. the day oestrus is first detected), using semen of Yorkshire boars. The animals were slaughtered between Day 5 and Day 12 after insemination and the embryos were flushed from the pregnant uterus within $5 \mathrm{~min}$ after death, using $30 \mathrm{ml}$ of a medium containing (w/v) $0.72 \% \mathrm{NaCl}, 0.045 \%$ $\mathrm{KCl}, 0.025 \% \mathrm{CaCl}_{2}, 0.02 \% \mathrm{KH}_{2} \mathrm{PO}_{4}, 0.038 \% \mathrm{MgSO}_{4}, 0.25 \% \mathrm{NaHCO}_{3}, 0.28 \%$ sodium lactate and $0.003 \%$ sodium pyruvate.

For routine transmission electron microscopy, embryos were fixed immediately after flushing in a fixative containing 3\% glutaraldehyde in $0.1 \mathrm{M}$-cacodylate buffer $(\mathrm{pH} 7.2)$ with $1 \%$ glucose for $1-1.5 \mathrm{~h}$ at room temperature, and post-fixed in $1 \%$ solution $\mathrm{OsO}_{4}$ for $1 \mathrm{~h}$ at $4^{\circ} \mathrm{C}$. After embedding in Epon 812, ultrathin sections were cut on a Reichert OMU IV ultramicrotome, using a Diatome diamond knife, and stained with uranyl acetate and lead citrate. Photographs were made with a Philips EM400 electron microscope. For light microscopy semi-thin sections were made from Epon-embedded embryos, and stained with $1 \%$ toluidine blue.

For the ferritin absorption experiments, 39 embryos of Days 5-12 were placed for $3-45 \mathrm{~min}$ at $37^{\circ} \mathrm{C}$ in fresh flushing medium containing $1 \%$ native ferritin (horse spleen, mol. wt. 800000 ; Merck. Darmstadt, FRG). In 26 other embryos, which were 9 or 10 days old, about $5 \mathrm{ml} 2.5 \%$ ferritin dissolved in flushing medium was injected into the blastocoele with a glass needle (tip-diameter $\sim 10 \mu \mathrm{m}$ ), mounted on a Leitz microinjection apparatus. Incubation was carried out for $3-45 \mathrm{~min}$ at $37^{\circ} \mathrm{C}$. Afterwards, the ferritin-incubated embryos were treated for routine electron microscopy as described above. Photographs were made of unstained sections.

For study of the relationship between embryoblast cell number and blastocyst diameter, 4 gilts received an intramuscular injection of $100 \mu \mathrm{g} \mathrm{GnRH}$ (Ovalyse ${ }^{\circledR}$, Upjohn, Ede, The Netherlands) $2 \mathrm{~h}$ after first detection of oestrus. Artificial insemination followed $24 \mathrm{~h}$ later. After slaughter at Day 11 after $\mathrm{GnRH}$, the blastocysts (51) were recovered by flushing the uterine horns with Dulbecco's phosphate-buffered saline (Gibco, Paisley, UK), and their diameter was measured. The embryos were immersed in a $1 \%$ sodium citrate solution for $5 \mathrm{~min}$ and fixed in methanol:acetic acid ( 3 : $1, \mathrm{v} / \mathrm{v})$. Embryos were stored in this medium at $-20^{\circ} \mathrm{C}$. The embryoblast was dissected from the trophectoderm and hypoblast, transferred to a drop of $70 \%$ acetic acid on an object glass, and cut into pieces. At $60^{\circ} \mathrm{C}$ the drop was distributed over the glass during drying. After xylene treatment for $20 \mathrm{~min}$, the nuclei were stained in $0.5 \%$ Giemsa for $20 \mathrm{~min}$, and counted. Two embryos were lost during the procedure.

\section{Results}

\section{General morphology of the blastocysts}

On Day 5, only morula stages were found. From Day 6 onwards, all embryos were in the blastocyst stage. Diameters varied from 0.1 to $0.2 \mathrm{~mm}$ on Day $5,0.1$ to $0.3 \mathrm{~mm}$ on Day $6,0.2$ to $2.1 \mathrm{~mm}$ on Day $8,0.3$ to $3.5 \mathrm{~mm}$ on Day 9 and 0.6 to $8.0 \mathrm{~mm}$ on Days 10 and 11 . At Day 11 spherical and tubular blastocysts were found and at Day 12 all embryos were tubular or filamentous. At Day 6, some embryos were still surrounded by the zona pellucida. Spherical hatched blastocysts were usually wrinkled after flushing. However, during short incubation at $37^{\circ} \mathrm{C}$ they were transformed into real spheres. 
From Day 6 onwards, trophectoderm cells contained numerous microvilli facing the uterine lumen. This polarity was not seen at Day 5. Distinct apical junctional complexes were also seen between adjacent trophectoderm cells from Day 6 onwards (Fig. 1). During the following days, the trophectoderm cells became more flattened as expansion proceeded.

At Day 7 hypoblast cells grew out from the inner cell mass and migrated along the trophectoderm (Figs 2, 3). From Day 8 onwards the flattened cells formed a continuous but fenestrated layer lining the blastocoele. Only near the embryoblast did the hypoblast cells appear cuboidal, with many microvilli projecting into the blastocoele.

At this stage, a well developed basal lamina (Fig. 4) separated the hypoblast from the trophectoderm and the embryoblast. This basal lamina was closely attached to the trophectoderm and embryoblast cells. Where polar trophectoderm covered the embryoblast the basal lamina did not follow this layer but deviated and followed the embryoblast cells, suggesting that the basal lamina originates from hypoblast-trophectoderm or hypoblast-embryoblast interaction. A space, at many places bridged by hypoblast filapodia, separated the hypoblast from the overlying cells (Fig. 4). Since the hypoblast cells showed wide fenestrations, this space made contact with the blastocoele.

At Day 11, during tubulation, the first mesoderm cells split off from the embryoblast and spread in between embryoblast or trophectoderm and hypoblast (Fig. 8). The undifferentiated cells made contact with each other by means of desmosomes.

\section{Ultrastructure of the developing embryoblast}

The embryoblast (or inner cell mass) was covered by the trophectoderm cells until Day 10 (Figs $5,6)$. The embryoblast of younger embryos consisted of irregularly shaped cells, which showed no clear polarity (Fig. 3). It had a maximum thickness of 5 cells. The cells were separated by wide intercellular spaces. Coated pits were seen at the surface of the cells lining these spaces and sometimes intracellular pinocytotic vesicles were present. Many cytoplasmic extensions projected into the intercellular spaces. Large yolk globules were present until the hypoblast layer had completely grown out. The cells were connected to each other and to the trophectoderm cells by desmosomes. During the 8th and 9th day, spaces of a specific type were formed between the superficial layers of embryoblast cells (Fig. 5). The cells lining these spaces, which ultimately will differentiate into embryonic ectoderm (epiblast), developed marked microvilli, projecting into the spaces. They had well developed junctional complexes connecting neighbouring cells (Fig. 10). Light microscopical observations of successive sections through the whole embryo showed that these spaces were in direct contact with the uterine lumen via small gaps in Rauber's layer. Consequently, they are part of the 'milieu exterieur' of the embryo.

During Days 9 and 10 these spaces seemed to unite into one large space (Figs 6,9). During the disappearance of Rauber's layer the epiblast stretched and extended. Its surface increased about 2-fold compared with the surface of the original Rauber's layer. The lining of the above mentioned space formed the new exterior of the embryoblast cells in a process of unfolding. During this unfolding process the thickness of the embryoblast decreased and after complete shedding of the Rauber's layer the embryoblast consisted of 2-3 layers of cells. The superficial cells were transformed to columnar polarized cells, closely attached and connected to each other and to trophectoderm cells by junctional complexes (Figs 7,9 ). Intercellular spaces were confined to the deeper part of the embryoblast.

\section{Macromolecular absorption}

The results of the ferritin experiments are summarized in Fig. 13. After hatching, ferritin, added to the culture medium, was visible in trophectoderm cells, including Rauber cells, but not in intercellular spaces. After 3 min of incubation it was present in caveolae at the surface of the cells, within pinocytotic vesicles (Fig. 11) and within larger vesicles. Even when incubation time was 45 min the 

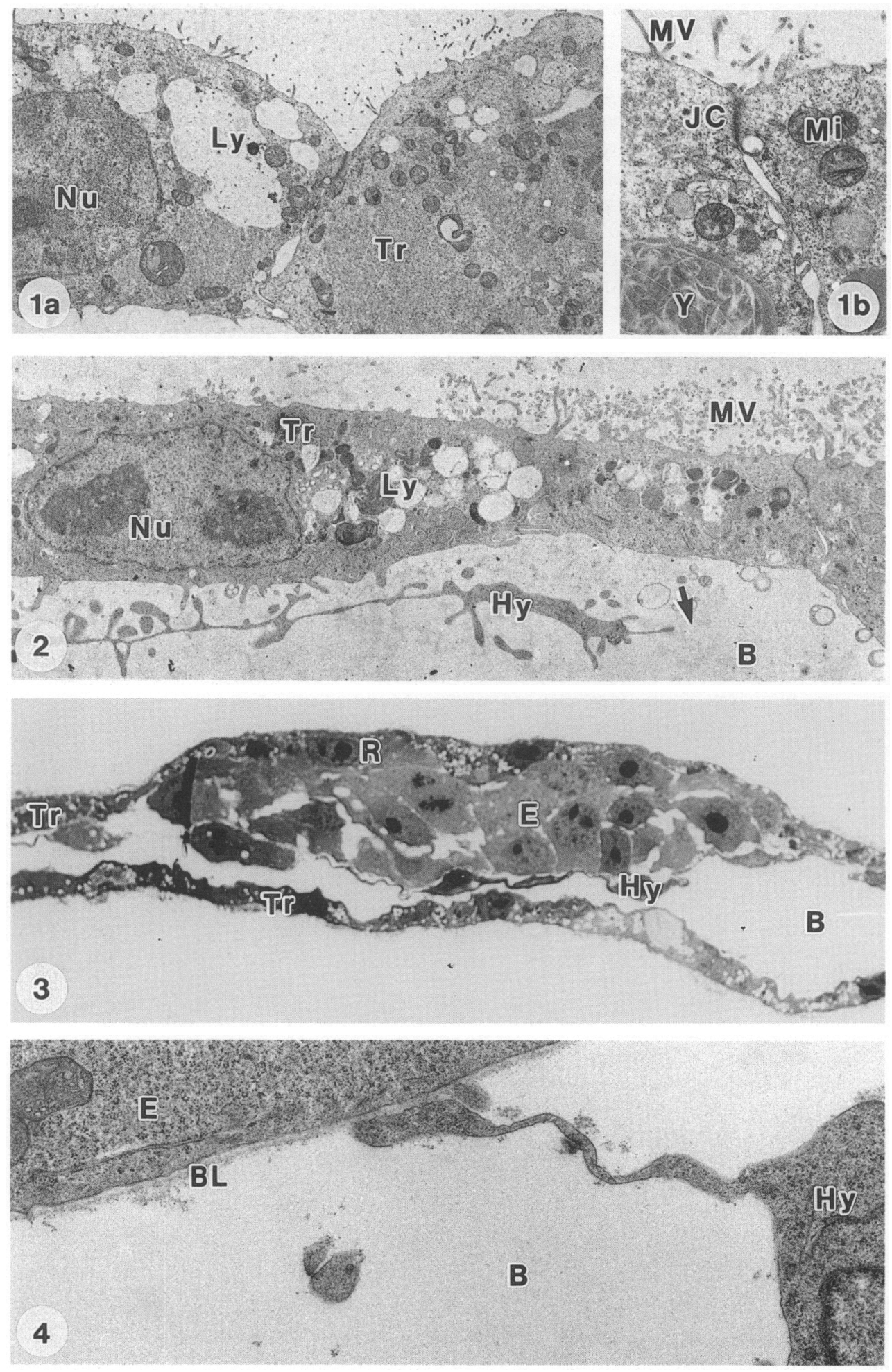
ferritin was only observed in the apical parts of the trophectoderm cells. Embryoblast and hypoblast cells did not contain any ferritin, before or after shedding of the Rauber cells.

When injected into the blastocoele of 9- and 10-day-old embryos, ferritin was present against and in the basal lamina under trophectoderm and embryoblast. Ferritin was readily taken up by hypoblast and trophectoderm cells: it was visible in vesicles inside the cytoplasm (Fig. 12). Ferritin was also traced in the intercellular space between trophectoderm cells up to the apical junctional complexes. Only in the embryoblast cells that are located against the basal lamina was some ferritin observed in vesicles basally within the cells.

\section{Embryoblast cell number and blastocyst diameter}

Figure 14 shows the diameter of the 49 Day-11 blastocysts in relation to embryoblast cell numbers. The blastocyst diameter varied from 1.7 to $5.3 \mathrm{~mm}$; the embryoblast cell number from 121 to 4457 . This variation was the result of both variation between and within litters. Within Litters A, C and D there was a difference in embryoblast cell numbers by a factor of 2 . However, in Litter B the range in embryoblast cell number was 16 -fold, although the variation in blastocyst diameter was not extreme. Even within one litter, blastocysts with virtually the same diameter differed largely in embryoblast cell number, showing that blastocyst diameter and embryoblast cell number were poorly correlated (Litter A: $r=-0 \cdot 16, P=0.63$; Litter B: $r=0.07, P=0.81$; Litter C: $r=0 \cdot 47, P=0 \cdot 14$; Litter D: $r=0 \cdot 29, P=0 \cdot 38$ ).

\section{Discussion}

The different developmental stages of pig embryos and their general morphological characteristics, as described in this study, are in accordance with previous data (Hunter, 1974; Anderson, 1978; Lindner \& Wright, 1978; Geisert et al., 1982; Stroband et al., 1984, 1986).

Our results suggest that in the pig polarization of the outer cells and their interconnection by junctional complexes are correlated to the process of compaction and, later on, blastulation, as holds for other mammals such as the mouse and rat (Ducibella, 1977; Reeve, 1981), and cow (Betteridge \& Fléchon, 1988). In the rat and the mouse, the development of intercellular junctions precedes blastocyst expansion (Schlafke \& Enders, 1967; Ducibella \& Anderson, 1975). The formation of junctional complexes is likely to be a prerequisite for transport processes through the outer cell layer. In the pig, extreme expansion of the blastocyst takes place during, and proceeds after, hatching, as holds for other ungulates (Betteridge \& Fléchon, 1988; Enders et al., 1988). Between Days 6 and 10 the volume of the blastocyst increases several thousands of times. Influx of fluid

Figs 1-4. General morphology of the blastocyst. $B=$ blastocoele; $B L=$ basal lamina; $\mathrm{E}=$ embryoblast; $\mathrm{Hy}=$ hypoblast; $\mathrm{JC}=$ junctional complex; Ly = lysosome; $\mathrm{Mi}=$ mitochondrium; $\mathrm{MV}=$ microvilli; $\mathrm{Nu}=$ nucleus; $\mathrm{R}=$ Rauber cell; $\mathrm{Tr}=$ trophoblast; $\mathrm{Y}=$ yolk.

Fig. 1. Transmission electron micrograph (TEM) of trophoblast cells of a just hatched Day-5 blastocyst. Note the microvilli on the outer surface of the cells, which are interconnected by junctional complexes. Some yolk globules are still present. Lysosomes have been developed. a, $\times 7000 ; \mathrm{b}, \times 20000$.

Fig. 2. TEM of a Day-7 trophoblast cell with underlying flattened hypoblast cell. The hypoblast layer is not continuous (arrow). $\times 5000$.

Fig. 3. Light microscopic micrograph (LM) of a Day-8 (collapsed) blastocyst, showing the embryoblast with non-polarized cells, covered by Rauber cells. Some hypoblast cells are visible beneath the embryoblast. $\times 800$.

Fig. 4. TEM. A hypoblast filapodium bridges the space between a hypoblast cell and the basal lamina of an embryoblast cell. Day $9, \times 17000$. 

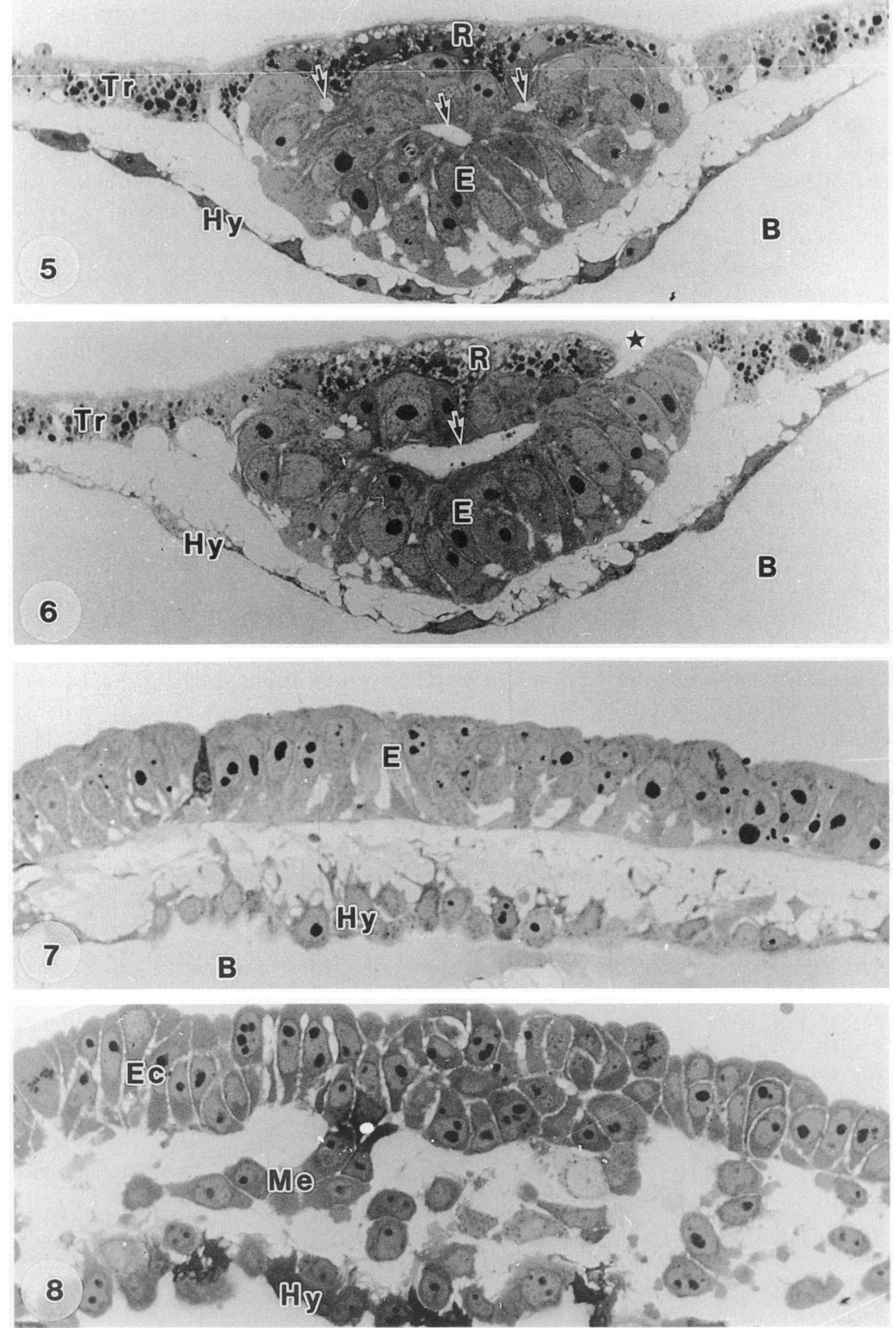
must be the main factor responsible for such an increase, which makes high demands upon the junctional complexes and the trophectoderm cells as a pumping mechanism. Both proliferation and flattening of the trophectoderm cells take place during expansion (Geisert et al., 1982).

The space between hypoblast and trophectoderm, only bridged by hypoblast filapodia, suggests that the trophectoderm is primarily responsible for the formation of the basal lamina, which is closely attached to it. Our data concerning the time of formation of the basal lamina suggest that the hypoblast cells induce its formation by the trophectoderm cells. According to Betteridge \& Fléchon (1988), hypoblast cells probably migrate along an acellular matrix. In contrast to our findings, Fléchon et al. (1987) found a basal lamina in the pig blastocyst before the hypoblast was formed. In cow (Linares \& Ploën, 1981) and sheep (Wintenberger-Torrès \& Fléchon, 1974) a basal lamina was not found before the blastocyst consisted of 2 layers of cells. Our finding, that a basal lamina was present between the ICM and hypoblast, while it was absent between the ICM and polar trophectoderm, also suggests that the hypoblast may induce its formation.

The presence of fenestrations in the extra-embryonic hypoblast has been previously described (Geisert et al., 1982; Stroband et al., 1984), but its significance is not clear. The connection of the space between hypoblast and trophectoderm with the blastocoele may facilitate transport processes.

In contrast to the trophectoderm, the cells of the ICM did not show early polarization or formation of junctional complexes. This is in accordance with observations on the pig (Norberg, 1973), cow (Betteridge \& Fléchon, 1988) and horse (Enders et al., 1988). The first signs of differentiation of part of the embryoblast into embryonic ectoderm or epiblast cells were seen only from Day 9 in our study.

Since expansion proceeds during and after shedding of the Rauber cells, the underlying embryoblast has to take over its function as a selective barrier since the hypoblast was found to be fenestrated. This is reflected by our findings showing the development of junctional complexes between ICM cells and between ICM and trophectoderm cells before disappearance of the polar trophectoderm. In the cow, signs of polarization were found in the outer parts of the ICM at Day 12, just before Rauber's layer was lost (Betteridge \& Fléchon, 1988).

Embryoblast cells, after becoming part of the surface of the blastocyst, obviously do not flatten during further expansion as do trophectoderm cells. Therefore, the mechanism of unfolding of the preformed embryonic ectoderm, as found in the pig during loss of polar trophectoderm, may prevent physical damage to this tissue and may maintain the integrity of the blastocyst. Furthermore, the rapid increase of the embryoblast surface area may cause rupture of Rauber's layer, which seems to be lost almost all at once in the pig, leaving only a few cells as remnants on the surface of the ICM (Geisert et al., 1982; Stroband et al., 1984). In the horse, such an unfolding process was not found: Enders et al. (1988) demonstrated that polar trophectoderm cells became dispersed over

Figs 5-8. Light micrographs of the developing embryoblast between Days 9 and 12 . $\mathrm{B}=$ blastocoele; $\mathrm{E}=$ embryoblast; $\mathrm{Ec}=$ ectoderm; $\mathrm{Hy}=$ hypoblast; $\mathrm{Me}=$ mesoderm; $\mathrm{R}=$ Rauber cell; $\mathrm{Tr}=$ trophoblast.

Fig. 5. The embryoblast cells on Day 9 are still covered by Rauber cells. They show some polarization compared with earlier stages (Fig. 3). Note the spaces (arrows) which develop within the embryoblast. $\times 500$.

Fig. 6. The spaces within the embryoblast of this Day-9 blastocyst are united into a large space (arrow). Note the disappearance of some Rauber cells (asterisk). $\times 500$.

Fig. 7. The embryoblast cells on Day 11 are transformed to columnar, polarized epiblast cells. The embryoblast is stretched now, and, probably as a result of this, the Rauber cells have disappeared. $\times 300$.

Fig. 8. Mesoderm cells on Day 12 are split off from the epiblast, forming the embryonic ectoderm. $\times 300$. 

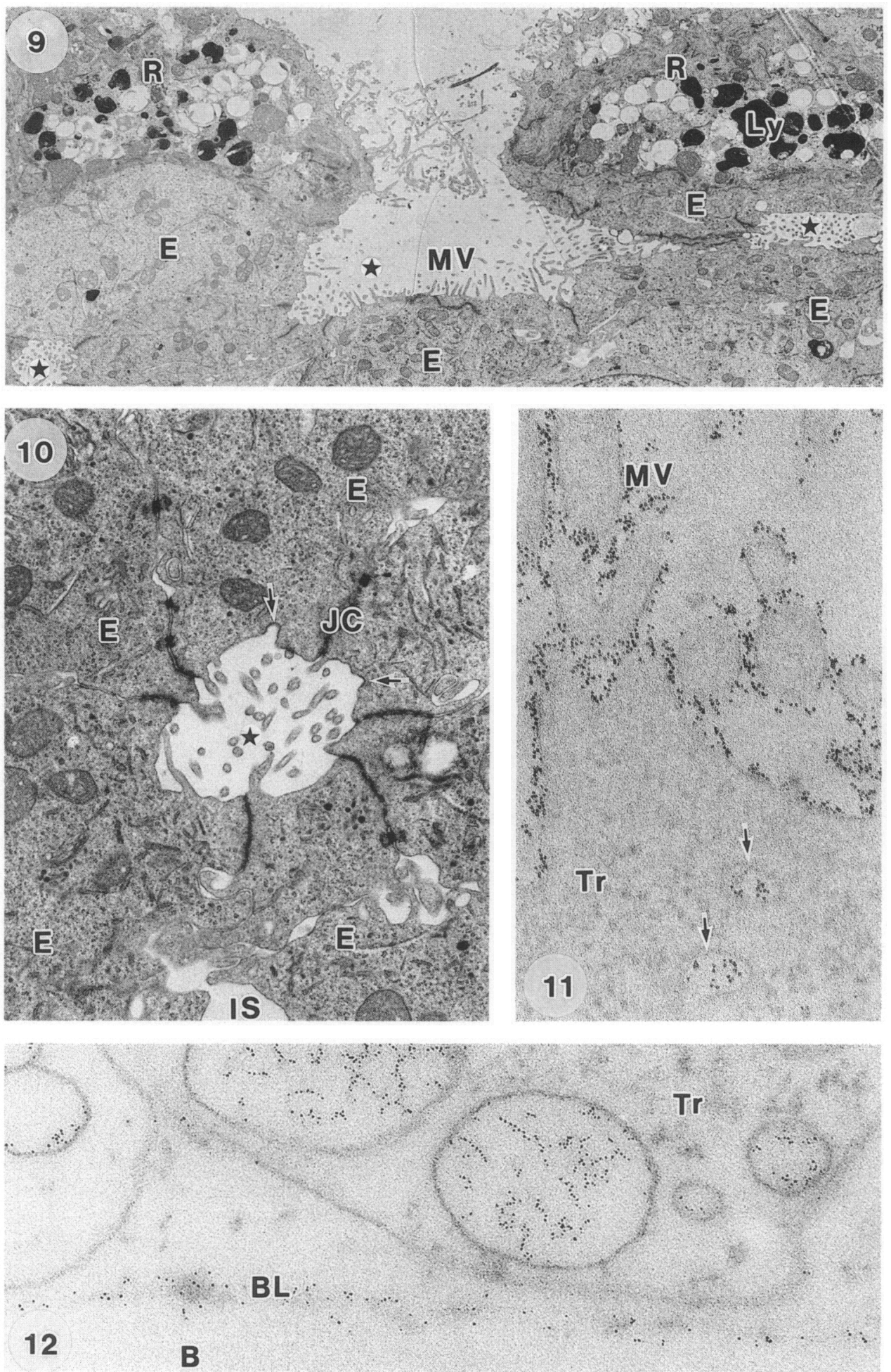
the surface of the embryoblast during expansion of the blastocyst. In contrast to the pig, in the horse the cells intermingle with embryoblast cells and appear to remain an integral part of the outer layer of the blastocyst for a number of days, before they finally disintegrate after the formation of a complete epiblastic shield.

Embryoblast cells do not only differ morphologically from trophectoderm cells. Our experiments showed that only the trophectoderm cells, including Rauber cells, took up ferritin from the exterior of the blastocyst. Embryoblast cells did not even absorb ferritin after shedding of Rauber's layer. These results confirm earlier studies on pig blastocysts (Stroband et al., 1984) but differ from those of Enders et al. (1988) on horse blastocysts, in which embryoblast cells showed large vacuoles containing cell debris after rupture of Rauber's layer, which was interpreted as due to phagocytotic uptake of necrotic polar trophectoderm cells. However, trophectoderm cells contained many more caveolae and coated pits, suggesting that the uptake of macromolecules is also a main function of trophectoderm tissue in the horse.

Trophectoderm cells of the pig, horse and cow contain many lysosomes. The uptake of ferritin appears to be followed by digestion in these structures, since no ferritin was found in intercellular spaces, or in basal parts of the cells. Nevertheless, maternal proteins have been found in the blastocoele of several mammalian species (Hafez, 1971; Beier, 1985), illustrating the selectivity of the trophectodermic barrier. The uptake of native ferritin mainly reflects fluid phase absorption. According to Fleming \& Goodall (1986) fluid phase-absorbed macromolecules are digested in the trophoblast lysosomal system, while membrane-coupled uptake also is related to transcytosis in the mouse.

We demonstrated the ability of hypoblast, embryoblast and trophectoderm cells to take up ferritin from the blastocoele. This is in accordance with ultrastructural features such as coated pits and pinocytotic vesicles along the basal and lateral membranes of these cells. Similar results were obtained in injection experiments carried out on mouse embryos (Fleming \& Goodall, 1986). Since cells of all three layers have the ability to absorb ferritin from the blastocoele, the absence of the tracer, after external supply, in all but trophoblast cells appears to be the result of a lack of transport to the blastocoele. This was also indicated by the absence of ferritin in intercellular spaces. Together these results underline the function of the outer layer of cells, formed by the trophoblast alone or the trophoblast and the embryoblast, as a, probably selective, barrier. The significance of the observed phenomena and the function of the substances dissolved in the blastocoelic fluid are unknown and further research is required.

The morphology of the embryoblast may also help to describe the developmental stage of the blastocyst accurately. This is important for the determination of between-litter and within-litter variation in development.

Figs 9-12. Transmission electron micrographs. $\quad \mathrm{B}=$ blastocoele; $\mathrm{BL}=$ basal lamina; $\mathrm{E}=$ embryoblast; IS = intercellular space; $\mathrm{JC}=$ junctional complex; Ly = lysosome; $\mathrm{MV}=$ microvilli; $\mathbf{R}=$ Rauber cell; $\mathrm{Tr}=$ trophoblast.

Fig. 9. Space (asterisk), similar to that in Fig. 6, in contact with the environment of the embryo (Day 9). Note the microvilli on the apices of embryoblast cells. $\times 3000$.

Fig. 10. Space similar to that shown in Figs 6 and 9 (asterisk) in more detail. Note the junctional complexes and microvilli on the apical surface of the embryoblast cells, this in contrast to the plasma membrane bordering intercellular spaces. Arrows point to some coated pits. $\times 11000$.

Fig. 11. Apical part of trophoblast cell after administration of ferritin to the medium. The tracer (black spots) is present at the apical outer surface of the cell and within some pinocytotic vesicles (arrows). $\times 84000$.

Fig. 12. Basal part of trophoblast cell of a Day-10 blastocyst after ferritin injection into the blastocoele. The tracer is present within the basal lamina and some vacuoles located basally within the trophoblast cell. $\times 58000$. 


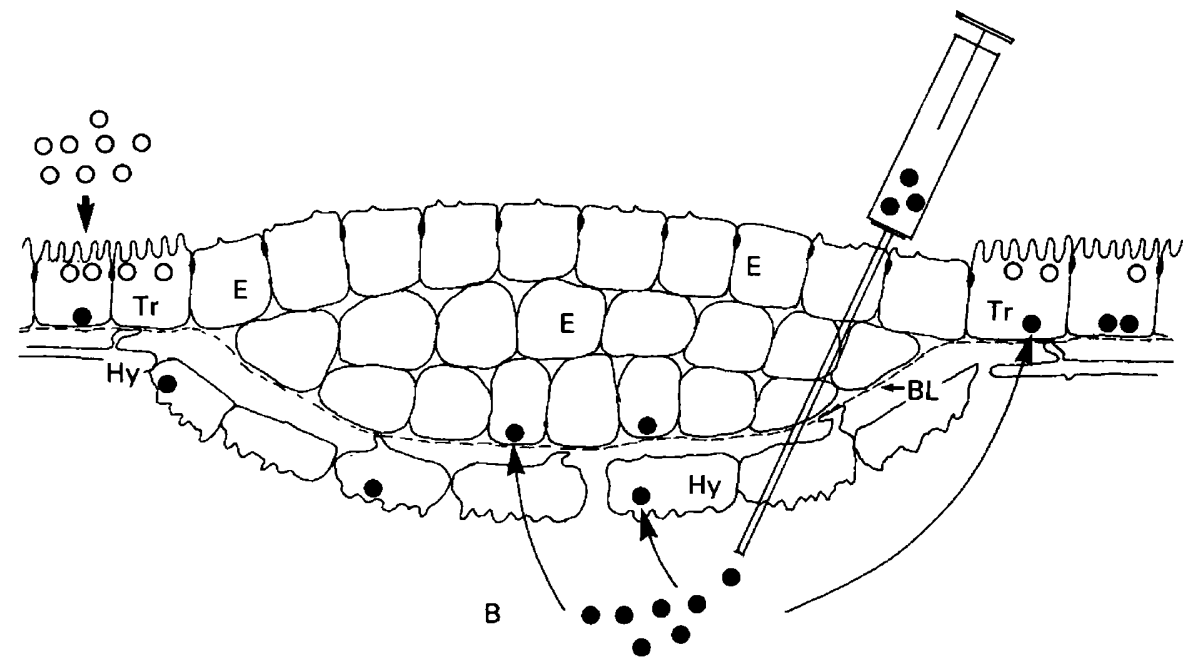

Fig. 13. Schematic drawing of the area of the blastocyst including the embryoblast after removal of Rauber cells. The location of ferritin molecules, administered via the medium $(O)$ or injected into the blastocoele $(\mathbf{O})$, is given. $\mathrm{B}=$ blastocoele; $\mathrm{BL}=$ basal lamina; $\mathrm{E}=$ embryoblast; $\mathrm{Hy}=$ hypoblast; $\mathrm{Tr}=$ trophoblast.

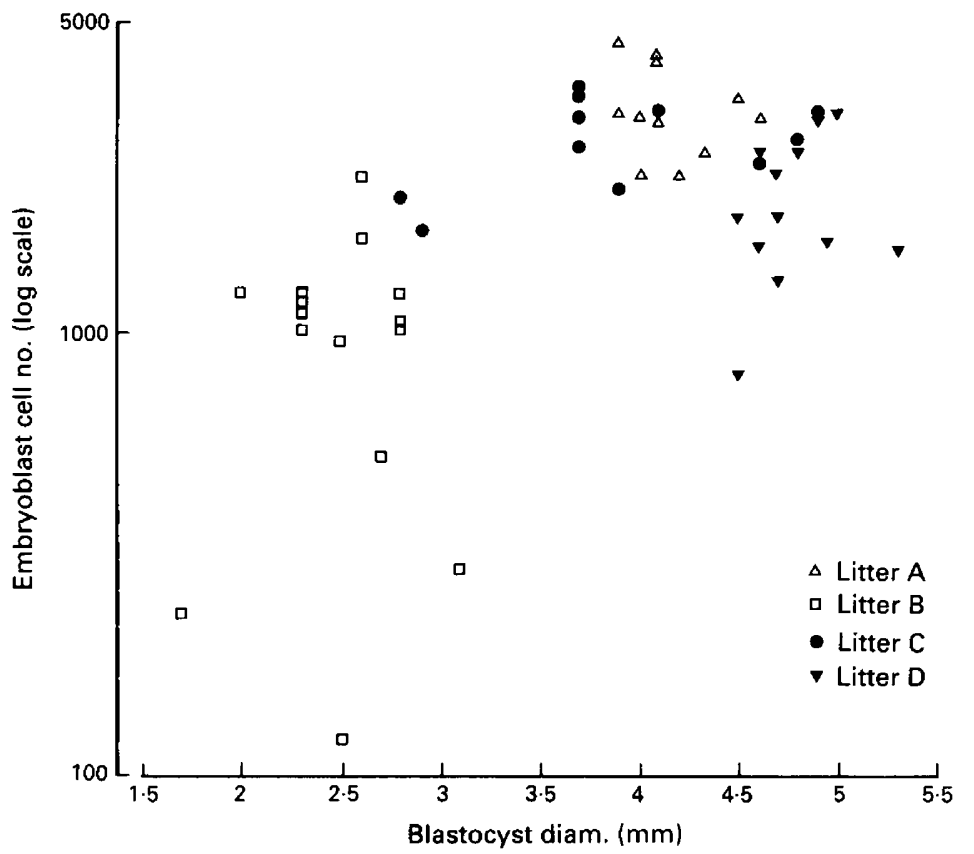

Fig. 14. Diameter and embryoblast cell number of 49 blastocysts from 4 gilts at Day 11 of pregnancy. 
The endogenous LH peak in the female pig may be found up to $24 \mathrm{~h}$ before or after first standing oestrus (Helmond et al., 1986). This is a cause of between-litter variation in embryonic development at the same time after insemination. In the present study, in an attempt to decrease this variation in the 4 experimental animals, GnRH was used to induce the LH peak. Despite this, variation of $24 \mathrm{~h}$ may be present in our material (the endogenous LH peak may have occurred before the GnRH injection). Variation due to other physiological differences between sows might also exist. Many sources of variation within litters may exist, including the embryonic genome and ovulation interval.

Our results show that the number of embryoblast cells is poorly correlated with blastocyst diameter. The size of the blastocyst and the cell number of the embryoblast are apparently not regulated by the same mechanism, and give different information on the developmental stage of an embryo. It is possible that variation in diameter mainly reflects the physiological status of the trophoblast cells, or, more specifically, the efficiency of the pumping mechanism that causes expansion. Gardner (1972) demonstrated that in the mouse the ICM regulates the proliferation of the trophectoderm. This could imply a certain ratio between the numbers of ICM and trophoblast cells. Our results are not in contrast to this hypothesis if we assume that the blastocyst diameter is not directly related to its total cell number, which we did not determine in this study.

We suggest that the extent of embryoblast development is a suitable morphological indicator for developmental stage of blastocysts, while the diameter of the latter may give information about certain aspects of trophoblastic physiological viability.

This work was carried out within the framework of the Research Group on Early Pregnancy of the Agricultural University.

We thank Professor L. P. M. Timmermans for critically reading the manuscript; Mr H. G. Elerie (TFDL) and $\mathrm{Mr}$ W. Valen for preparing the illustrations; other members of the Research Group on Early Pregnancy, especially Dr T. van der Lende, for many discussions; and staff of 'De Haar Varkens' for providing the gilts used and carrying out detection of oestrus.

\section{References}

Anderson, L.L. (1978) Growth, protein content and distribution of early pig embryos. Anat. Rec. 190, 143-154.

Beier, H.M. (1985) Proteins and steroids in early pregnancy. In Early Pregnancy Factors, pp. 1-11. Eds F. Ellendorff \& E. Koch. Perinatology Press, Ithaca.

Betteridge, J.K. \& Fléchon, J.E. (1988) The anatomy and physiology of preattachment bovine embryos. Theriogenology 29, 155-187.

Biggers, J.D., Bell, J.E. \& Benos, D.J. (1988) Mammalian blastocyst: transport functions in a developing epithelium. Am. J. Physiol. 255, C419-C432.

Dantzer, V. (1985) Electronmicroscopy of the initial stages of placentation in the pig. Anat. Embryol. 172, $281-293$.

Ducibella, T. (1977) Surface changes of the developing trophoblast cell. In Development in Mammals, vol. 1, pp. 5-30. Ed. M. H. Johnson. North Holland, Amsterdam.

Ducibella, T. \& Anderson, E. (1975) Cell shape and membrane changes in the eight-cell mouse embryo: pre-requisites for morphogenesis of the blastocyst. Devl Biol. 47, 45-58.

Enders, A.C., Lantz, K.C., Liu, I.K.M. \& Schlafke, S. (1988) Loss of polar trophoblast during differentiation of the blastocyst of the horse. J. Reprod. Fert. $83,447-460$.
Fléchon, B., Richoux, V. \& Fléchon, J.E. (1987) Differenciation et elongation du blastocyste de porc. Biol. Cell. 60, 31a, abstr.

Fleming, T.P. \& Goodall, H. (1986) Endocytic traffic in trophectoderm and polarised blastomeres of the mouse preimplantation embryo. Anat. Rec. 216, 490-503.

Gardner, R.L. (1972) An investigation of inner cell mass and trophoblast tissues following their isolation from the mouse blastocyst. J. Embryol. exp. Morph. 28, 279-312.

Geisert, R.D., Brookbank, J.W., Roberts, R.M. \& Bazer, F.W. (1982) Establishment of pregnancy in the pig. II. Cellular remodelling of the porcine blastocyst during elongation on Day 12 of pregnancy. Biol. Reprod. 27, 941-955.

Hafez, E.S.E. (1971) Some maternal factors affecting physicochemical properties of the blastocyst. In The Biology of the Blastocyst, pp. 139-192. Ed. R. J. Blandau. University of Chicago Press.

Helmond, F., Aarnink, A. \& Oudenaarden, C. (1986) Periovulatory hormone profiles in relation to embryonic development and mortality in pigs. In Embryonic Mortality in Farm Animals, pp. 119-125. Eds J. M. Sreenan \& M. G. Diskin. Martinus Nijhoff, Dordrecht. 
Hunter, R.H.F. (1974) Chronological and cytological details of fertilization and early embryonic development in the domestic pig, Sus scrofa. Anat. Rec. 178, $169-186$.

Hunter, R.H.F. (1977) Physiological factors influencing ovulation, fertilization, early embryonic development and establishment of pregnancy in pigs. Br. vet. J. 133, $461-470$.

Kaufman, M.H. (1983) The origin, properties and fate of trophoblast in the mouse. In The Biology of the Trophoblast, pp. 23-68. Eds Y. W. Loke \& A. Whyte. Elsevier, Amsterdam.

Linares, T. \& Ploën, L. (1981) On the ultrastructure of seven day old normal (blastocyst) and abnormal bovine embryos. Anat. Histol. Embryol. 10, 212-226.

Lindner, G.M. \& Wright, R.W. (1978) Morphological and quantitative aspects of the development of swine embryos in vitro. J. Anim. Sci. 46, 711-718.

McLaren, A. \& Smith, R. (1977) Functional test of tight junctions in the mouse blastocyst. Nature, Lond. 267, $351-353$.

Norberg, H.S. (1973) Ultrastructural aspects of the preattached pig embryo: cleavage and early blastocyst stages. Z. Anat. EntwGesch. 143, 94-114.

Perry, J.S. \& Rowlands, I.W. (1962) Early pregnancy in the pig. J. Reprod. Fert. 4, 175-188.

Pope, W.F. \& First, N.L. (1985) Factors affecting the survival of pig embryos. Theriogenology 23, 91-105.

Pope, W.F., Lawyer, M.S., Nara, B.S. \& First, N.L. (1986) Effect of asynchronous superinduction on embryo survival and range of blastocyst development in swine. Biol. Reprod. 35, 133-137.

Reeve, W.J.D. (1981) Cytoplasmic polarization develops at compaction in rat and mouse embryos. J. Embryol. exp. Morphol. 62, 351-367.

Schlafke, S. \& Enders, A.C. (1967) Cytological changes during cleavage and blastocyst formation in the rat. J. Anat. 102, 13-32.

Stroband, H.W.J., Taverne, N. \& van den Bogaard, M. (1984) The pig blastocyst: its ultrastructure and the uptake of protein macromolecules. Cell Tissue Res. 235, 347-356.

Stroband, H.W.J., Taverne, N., Langenfeld, K. \& Barends, P.M.G. (1986) The ultrastructure of the uterine epithelium of the pig during the estrous cycle and early pregnancy. Cell Tissue Res. 246, 81-89.

Wilmut, I., Sales, D.I. \& Ashworth, C.J. (1985) The influence of variation in embryo stage and maternal hormone profiles on embryo survival in farm animals. Theriogenology 23, 107-119.

Wintenberger-Torrès, S. \& Fléchon, J.E. (1974) Ultrastructural evolution of the trophoblast cells of the preimplantation sheep blastocyst from Day 8 to Day 18. J. Anat. 118, 143-153.

Wright, R.W., Grammer, J., Bondioli, K., Kuzan, F. \& Menino, A. (1983) Protein content and volume of early porcine blastocysts. Anim. Reprod. Sci. 5, 207-212.

Received 14 March 1989 